Eduvest - Journal of Universal Studies

Volume 1 Number 12, December 2021

p- ISSN 2775-3735 e-ISSN 2775-3727

\title{
THE USE OF MISIS-PRETY APPLICATION (MINDFULNESS SPIRITUAL OF ISLAM FOR PRENATAL ANXIETY) TOWARD CHILDBIRTH ANXIETY IN COVID-19 PANDEMIC
}

\section{Tiyara Safitri, Sri Sumarni, Aris Santjaka}

Health Polytechnic of the Ministry of Health Semarang, Indonesia

E-mail: tyara_sardie@yahoo.com, marninugroho@yahoo.com, arissantjaka@gmail.com

\begin{tabular}{|c|c|}
\hline ARTICLE INFO & ABSTRACT \\
\hline $\begin{array}{l}\text { Received: } \\
\text { November, } 26^{\text {th }} \\
2021 \\
\text { Revised: } \\
\text { December, } 17^{\text {th }} \\
2021 \\
\text { Approved: } \\
\text { December, 19th } \\
2021\end{array}$ & $\begin{array}{l}\text { Background: Reports show the prenatal anxiety of } \\
\text { Indonesia reaches a percentage of } 28.7 \% \text { of mothers } \\
\text { experience anxiety. The COVID-19 pandemic influences } \\
\text { pregnant mothers' psychology, } 76.2 \% \text {. The physical, } \\
\text { psychological, and spiritual balance of pregnant mothers } \\
\text { should be healthily balanced. This healthy balance } \\
\text { includes the childbirth process to avoid psychological } \\
\text { interruption. The use of android application information } \\
\text { for obstetric service could improve maternal quality by } \\
\text { providing intervention autonomously. Method: This } \\
\text { Research \& Development used True Experimental Pre and } \\
\text { Post-test with Control Group Design. The intervention was } \\
\text { with MiSIs-PreTy application to lose the anxiety of } \\
\text { primipara pregnant mothers with Trimester III status on } \\
\text { the experimental group for } 7 \text { days. Every day, the mothers } \\
\text { received } 30 \text { minutes of implementation. The positive } \\
\text { control group, on the other hand, received health } \\
\text { education about childbirth preparation. The researchers } \\
\text { took } 30 \text { respondents as the samples randomly. The data } \\
\text { analysis was tested with non-parametric Wilcoxon and } \\
\text { Mann Whitney tests. Results: The experts' validation } \\
\text { about the developed application reliability obtained an }\end{array}$ \\
\hline
\end{tabular}

Tiyara Safitri, Sri Sumarni, Aris Santjaka (2021). The Use of MisisPrety Application (Mindfulness Spiritual of Islam for Prenatal Anxiety) Toward Childbirth Anxiety in Covid-19 Pandemic.

How to cite:

E-ISSN: Journal Eduvest. 1(12): 1579-

Published by: 


\begin{tabular}{|c|c|}
\hline & $\begin{array}{l}\text { average score of } 92.80 \% \text { from six aspects. They were } \\
\text { based on the ISO } 9126 \text { software's quality, such as } \\
\text { usability, reliability, functionality, efficiency, } \\
\text { maintainability, and portability. The experiment used the } \\
\text { given intervention for both groups. It was effective to lose } \\
\text { the anxiety. The effectiveness for experimental group was } \\
p<0.001 \text { while control group obtained } p<0.005 \text {. } \\
\text { However, the use of the developed application was more } \\
\text { effective to lose the anxiety with an average score of } \\
11,8 \pm 5,414 \text { for the experimental group than the positive } \\
\text { control group with } 4,46 \pm 4,24 \text {. Conclusion: The developed } \\
\text { application, MiSls-PreTy, was validated and revised to be } \\
\text { more effective to lose the anxiety of pregnant mothers. } \\
\text { Further researches could develop the findings by adding } \\
\text { some variables, such as childbirth self-efficacy as the valid } \\
\text { measuring tool to examine the pregnant mothers' belief } \\
\text { to give birth. }\end{array}$ \\
\hline KEYWORDS & $\begin{array}{l}\text { Mindfulness, Spiritual Mindfulness, Prenatal Anxiety, } \\
\text { Childbirth Anxiety, COVID-19 }\end{array}$ \\
\hline (cc) (†) & $\begin{array}{l}\text { This work is licensed under a Creative Commons } \\
\text { Attribution-ShareAlike } 4.0 \text { International }\end{array}$ \\
\hline
\end{tabular}

\section{INTRODUCTION}

Pregnancy, childbirth, and postpartum are physiological and natural. Physical and psychological changes make mothers feel uncomfortable. The changes also trigger mood swings or mental imbalance. This imbalance triggers stress and anxiety during childbirth (Harahap, 2018). Anxiety leads to unreadiness for mothers to deal with childbirth. This situation influences the self-esteem of pregnant mothers to deliver their babies (Munkhondya et al., 2020).

The anxiety may occur in both primipara and multipara mothers. Mothers with the first pregnancy experience, primigravida, have strong anxiety than those multipara mothers (Shodiqoh and Syahrul, 2014). The anxiety raises during the Trimester III of pregnancy due to the childbirth process (Zengin et al., 2020).

The prevalence of psychological problems in developing countries with high risk is $15.6 \%$ for pregnant mothers. Then, a percentage of $19.8 \%$ occurs on postpartum mothers (Organization, 2014). The psychological problems also occur in various advanced countries, such as France with a percentage of $7.9 \%$ primigravida mothers suffering from anxiety, $11.8 \%$ of primigravida mothers suffering from depression, and $13.2 \%$ of primigravida mothers suffering both anxiety and depression (Ibanez et al., 2015).

The percentage of prenatal anxiety in Indonesia is reported with a percentage of $28.7 \%$ from 107.000.000 mothers suffering from anxiety. Other studies showed a percentage of $53.3 \%$ of mothers suffering from childbirth anxiety (Heriani, 2016).

A percentage of $25-50 \%$ mortality rate of the fertile maternal period is caused due to mortality rate and illness rate of maternal mothers (Prawirohardjo, 2008). Based on the 
Census Rate Survey in 2015, the mortality rate ratio of mothers in Indonesia is 305/100.000 live-born. The government struggles to lower the mortality rate into 232/100.000 live-born (Nurya Viandika, Kes, and Husada, 2020).

The unmanaged anxiety impact on pregnancy may cause complications, such as premature birth, lower birth weight, and slower fetal development (Ciesielski, Marsit and Williams, 2015); depression on postpartum mothers, and lower breast milk provision (Becker et al., 2016). These impacts can be anticipated with the obstetric service model, proposed by WHO. It is Midwife-Led Continuity of Care (MLCC). The service perceives an obstetrician to support women during the antenatal, intrapartum, and postnatal periods (Sandall et al., 2016).

The COVID-19 pandemic effect on maternity is $76.2 \%$ influencing the psychological aspect of pregnant women. The significant statistical effect of the COVID19 pandemic on the anxiety and depression of pregnant women obtains a p-value of 0.001 (Durankuş and Aksu, 2020; Wu et al., 2020). Some efforts to lose the anxiety of pregnant mothers are with mind-body intervention with autogenic training; biofeedback, imagery, meditation, praying, autosuggestion, yoga, and hypnotherapy (Kuswandy, 2011).

Studies found the effectiveness of losing anxiety during childbirth, such as with virtual reality (VR), Hypno pregnancy, gentle yoga, implementation of Al-Qur'an Murotal, and therapeutic communication (Karyati, 2016; Ritsma Zunira Aryani, Rohmi Handayani, 2018; Dian Puspitasari1, 2019; Riska, Purwara and Ganiem, 2020). Studies about prenatal yoga found the influence of yoga on quick delivery speed. The study showed increasing endorphin hormone (Kartikasari, Hadisaputro, and Sumarni, 2020).

Studies of the spiritual approach found the approach could facilitate individuals to be successful. The spiritual approach, with a focus toward God, is something originating from inner individuals (Faizah and Sudarmiati, 2017). This approach also influences the childbirth process, including higher self-esteem of psychological problems (Yuniarti et al., 2016). Mindfulness refers to an approach to holistic health intervention. It could be applied based on cultural needs or community beliefs (Dwidiyanti et al., 2019). The spiritual approach deals with the belief in God, the Almighty, and the Creator (Parrott, 2017).

Mindfulness implementation of Islamic spiritual is an exercise to remember Allah the Almighty as the Only God. Thus, the individuals always involve Him in every process, especially dealing with pregnancy. This involvement will involve consciousness to understand the condition that the experienced matter is not a coincidence but has been planned by Allah the Almighty (Dwidiyanti, Pamungkas, and Ningsih, 2018). It encourages self-acceptance practice, and conscious awareness and emotions (Putri and Yuliandari Gunatirin, 2020).

A systematic review about effective mindfulness exercise toward the mental health of maternal mothers, by Helen Hall, found that the exercise could develop the childbirth capability of the mothers (Hall et al., 2015). Other research also found mindfulness could solve anxiety problems during antenatal, empower the mothers, and improve delivery satisfaction (Fisher et al., 2012).

Mental health, according to WHO, cited by Hawari (2011), deals with psychological, biological, social, and spiritual health (Fitriyani et al., 2018). A study about the effort to realize safe and comfortable childbirth found the level of stress could be milder and lower after providing spiritual intervention (Nurrochmi, Nurlina, and Padmawati, 2019). A study by Aslami et al (2016) found Islamic spiritual-based mindfulness could lower anxiety and depression of pregnant mothers than cognitivebased behavior (Aslami et al., 2017). Rita Jayanti (2016) also argue spiritual-based 


\section{Tiyara Safitri, Sri Sumarni, Aris Santjaka}

mindfulness was effective to improve psychological wellbeing than exercise for diabetes mellitus type 2 sufferers (Jayanti, 2016).

The pocketbook for pregnant mothers and newborn babies, by the Minister of Health of Republic Indonesia in 2020, explains that in this COVID-19 pandemic, Antenatal Care visits (ANC) and maternity class visits should be postponed (Dirjen Kesmas, 2020). This limitation lowers ANC comprehension. Thus, it is important to use service of the online method to ensure the service is comprehensive without a face-to-face meeting.

The vast technological development allows obstetric service to occur via Android-based smartphone utilization. In this world, a percentage of $90 \%$ of adults have a smartphone (PERRIN, 2015). In this research, the researchers used information technology utilization with a smartphone as the gap to fill. Thus, the researchers conducted a study to develop MiSIs-PreTy application as the alternative to lower the anxiety of pregnant mothers to face the childbirth process during the COVID-19 pandemic. The intervention model was realized into recorded audio. These audios could be listed daily. The audio is 30 minutes long and was played for 7 days autonomously. This procedure aimed to support the psychological and spiritual needs of pregnant mothers.

\section{RESEARCH METHOD}

\section{Research type and design}

This Research \& Development aimed to develop the MiSIs-PreTy application. The name stands for Mindfulness Spiritual Islam for Prenatal Anxiety. It provides mindfulness spiritual Islam directly for pregnant women in Trimester III via online media by using android-based application media. This application can be downloaded and is the research's product.

Research \& Development is a method to find, develop, improve, and produce products. Then, the results are examined to create standardized products (Sugiyono, 2014). Based on the Research \& Development by Borgh \& Gall, modified by Sugiyono, $\mathrm{R} \& \mathrm{D}$ describes the stages or procedural plots descriptively to produce a product or develop the existing product. The development also aims to improve effectiveness and efficiency. The products could be modules, books, applications, training videos, and learning videos.

The research used true experimental with pre-test and post-test with control group design. This research consisted of two groups. The first group, the experimental group, received intervention with the MiSIs-PreTy application.

In this research, the researchers used the probability sampling technique. It was random sampling in which the sampling technique was done with the lottery. The researchers took the sample by screening the initial anxiety of the pregnant mothers. Then, they selected the sample by putting 30 numbers written on rolled papers. The first stage was determining the experimental respondent with lottery numbers.

\section{Population and sample}

The population in this research consisted of all primipara pregnant mothers in Trimester III listed in Cohort of Maternal Mother Cohort of Health Agency, Bintan Regency, from March until April 2021. There were 64 respondents. Based on the calculation of the minimum sample size, the researchers used fifteen respondents. Thus, the researchers took both group samples, 30 respondents.

The sample of this research consisted of some primipara mothers in Trimester III. They were considered to represent the population and meet the inclusion and exclusion skills. 


\begin{tabular}{|c|c|c|c|c|c|}
\hline \multirow{2}{*}{\multicolumn{2}{|c|}{ Validators/Experts }} & $\mathrm{V}$ & & Percent & \multirow[b]{2}{*}{ ean } \\
\hline & & $\begin{array}{l}\text { alidation } \\
\text { score }\end{array}$ & age & & \\
\hline $\begin{array}{l}\text { Dr. Meidiana Dwidiyanti, S.Kp., } \\
\text { M.Sc }\end{array}$ & 5 & 18 & & $94,40 \%$ & \\
\hline Muhammad Irfan, ST & 5 & 21 & & $96,80 \%$ & $92,80 \%$ \\
\hline Nuzulia Rahma, S.Psi., Psi & 5 & 09 & & $87,20 \%$ & \\
\hline
\end{tabular}

\section{RESULT AND DISCUSSION}

\section{Table 1. Expert Validation Test Result}

Table 1 shows the validity test result of MiSIs-PreTy concerning the Mindfulness Spiritual Islam is $94.40 \%$. Then, the information and technology media experts scored the Mindfulness Spiritual Islam with a percentage of $96.80 \%$. Then, the psychological experts of Maternal Mental Health scored with a percentage of $87.20 \%$. The reliability test average score of the MiSIs-PreTy application is $92.80 \%$, categorized high. It indicates the developed application was readable to test in a trial run with a limited population. Thus, the effectiveness of MiSIs-PreTy to lose the anxiety could be measured.

After being validated and receiving the recommendation for the application design, the researchers revised the product. The initial revision was done by revising the materials input in the application.

Then, the revision was done based on the expert of Maternal Mental Health dealing with the colors, texts, and icons that influenced the psychology of the mothers.

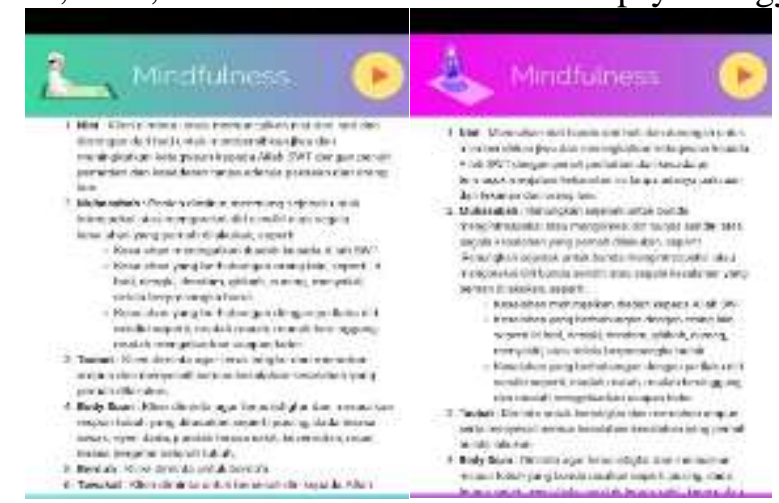

Figure 1. Exercise for revising text about mindfulness spiritual: left (before) and after (right)

Table 2. The Normality test of Anxiety Score of Experimental Group and Control Group

\begin{tabular}{llll}
\hline \multirow{2}{*}{ Groups } & Variables & p-value* & Remarks \\
& Anxiety Score & & \\
\hline Experiment & Pretest & 0,633 & Normal \\
& Post-test & 0,003 & Abnormal \\
\hline Control & Pretest & 0,023 & Abnormal \\
& Post-test & 0,450 & Normal \\
\hline
\end{tabular}




\section{Tiyara Safitri, Sri Sumarni, Aris Santjaka}

Table 2 shows the data are not normally distributed with $a$ p-value $<0.05$ on the control group's pretest. The obtained p-value is 0.023 . Then, the posttest data of the experimental group obtain a p-value of 0.003 . The pretest of the experimental group has normal data distribution with a p-value of 0.633 for the experimental group and a p-value of 0.450 for the control group. The scores indicated the data distribution is not normal. Therefore, the researchers used a non-parametric test, the Wilcoxon test, to pair the data. The researchers also used Mann Whitney test for unpaired data to see the effectiveness differences from both groups.

Table 3. The Effectiveness Test Score of Primipara Mothers' Anxiety on TM III for Experimental and Control Groups

\begin{tabular}{llccc}
\hline Groups & & Mean \pm SD & Min-Max & p-value* \\
\hline Experiment & Pretest & $26,67 \pm 5,960$ & $16-35$ & 0,001 \\
& Post-test & $14,87 \pm 5,041$ & $10-25$ & \\
\hline Control & Pretest & $28,8 \pm 4,784$ & $19-34$ & 0,005 \\
& Post test & $24,33 \pm 4,169$ & $18-32$ & \\
\hline
\end{tabular}

Table 3 shows the conditions before and after the intervention. The minimum and maximum scores of the mothers' anxiety for both groups are lower. The results of the paired variable test for primipara mothers' anxiety obtain a p-value of 0.001 for the experimental group and a p-value of 0.005 for the control group. Both groups obtain $\mathrm{p}$ value $<0.05$. It means the use of MiSIs-PreTy was effective to lose childbirth anxiety by providing health education and effective childbirth preparation. Here are the comparative test results or the anxiety score changes for each variable.

Table 4. The Anxiety Score Changes of Primipara Mothers with TM III for Experimental and Control Groups

\begin{tabular}{|c|c|c|c|c|c|c|}
\hline \multirow[t]{3}{*}{ Groups } & Mean \pm SI & & & \multirow[t]{3}{*}{$p$-value* } & \multirow{3}{*}{$\begin{array}{l}\Delta \text { Mean } \pm \text { SD } \\
\text { pre-post }\end{array}$} & \multirow[t]{3}{*}{$p$-value* } \\
\hline & \multicolumn{2}{|c|}{$\mathrm{P}$} & $\mathrm{P}$ & & & \\
\hline & retest & osttest & & & & \\
\hline $\begin{array}{l}\text { Experi } \\
\text { ment }\end{array}$ & $\begin{array}{l}26,67 \pm \\
5,960\end{array}$ & $\begin{array}{l}14,87 \\
5,041\end{array}$ & \pm & 0,000 & $11,8 \pm 5,414$ & \\
\hline Control & $\begin{array}{l}28,8 \quad \pm \\
4,784\end{array}$ & $\begin{array}{l}24,33 \\
4,169\end{array}$ & \pm & 0,009 & $4,46 \pm 4,24$ & 0,001 \\
\hline
\end{tabular}

Table 4 shows $\mathrm{p}$-value of experimental group is 0.000 , p-value $<0.05$. On the other hand, the p-value of the control group is 0.009 , $\mathrm{p}$-value $<0.05$. It means there are significant differences between the anxiety scores for both groups, before and after the intervention. The anxiety average score pretest of the experimental group is 26.67 . Then, after the intervention, the score lowers to 14.87. It has an 11.8 decrease. On the other hand, the average pretest score of anxiety is 28.8 . Then, after being intervened, the score lowered to 24.33. The low score was not significant as the experimental group was, 4.46. Thus, the decreasing score of anxiety was greatly found in the experimental group than the positive control group.

The unpaired data test analysis with $p$-value delta $(\Delta)$ mean is 0.001 (p-value < 0.05). It means the use of MiSIs-PreTy application for the experimental group was effective to lose the anxiety score than the control group treated with health education about childbirth to decrease the childbirth anxiety. The evidence is the delta score with the average score of decreasing rate for the control group is $4.46(14 \%)$ while the experimental group is $11.8(44 \%)$. 
After obtaining the anxiety scores from the pre-test and post-test of the trial run, the researchers evaluated and distributed the questionnaire to judge the developed application online for the respondents.

The researchers found, during the limited test, that MiSIs-PreTy was effective to lower the childbirth anxiety for primipara mothers during the COVID-19 pandemic. The evidence was the research data analysis. It obtained a p-value $<0.05$ with a degree of freedom (CI) of $95 \%$. From the data, the researchers revised the application greatly. The researchers also used audio to promote mindfulness with tender sound. This matter was suggested by a psychologist to make the mothers feel comfortable while listening and doing the stage. The other consideration was - changing the application algorithm. The respondents had to fill the pretest of anxiety before accessing the existing information to avoid research biases

\section{CONCLUSION}

From the research, the researchers concluded that the development and researching process about the use of MiSIs-PreTy, Mindfulness Spiritual Islam for Prenatal Anxiety, toward childbirth anxiety during the COVID-19 pandemic lasted with seven procedural stages of R\&D. The product obtained an average score of $92.80 \%$ from experts based on six aspects of software quality, ISO 9126. They were usability, reliability, functionality, efficiency, maintainability, and portability. The use of MiSIsPreTy was effective to lose the anxiety of childbirth in the COVID-19 pandemic with a pvalue of 0.001 . There were significant differences in MiSIs-PreTy application uses with an anxiety score $200 \%$ higher than the provision of health education about childbirth preparation.

\section{REFERENCES}

Abdollahpour, S. And Khadivzadeh, T. (2020) 'Improving The Quality Of Care In Pregnancy And Childbirth With Coronavirus (Covid-19): A Systematic Review, Journal Of Maternal-Fetal And Neonatal Medicine. Taylor \& Francis, 0(0), Pp. 1-9. Doi: 10.1080/14767058.2020.1759540.

Aslami, E. Et Al. (2017) 'A Comparative Study Of Mindfulness Efficiency Based

On Islamic-Spiritual Schemes And Group Cognitive-Behavioral Therapy On Reduction Of Anxiety And Depression In Pregnant Women', International Journal Of Community Based Nursing And Midwifery, 5(2), Pp. 144-152.

Azwar, A. And Prihartono, J. (2014) 'Metodologi Penelitian Kedokteran \& Kesehatan Masyarakat', Tangerang: Binarupa Aksara.

Becker, M. Et Al. (2016) 'Depression During Pregnancy And Postpartum', Current Psychiatry Reports, 18(3), Pp. 1-9. Doi: 10.1007/S11920-0160664-7.

Ciesielski, T. H., Marsit, C. J. And Williams, S. M. (2015) 'Maternal Psychiatric Disease And Epigenetic Evidence Suggest A Common Biology For Poor Fetal Growth', Bmc Pregnancy And Childbirth. Springer, 15(1), Pp. 1-9.

Dian Puspitasari1, R. K. (2019) 'The Effect Of Hypnopregnancy On Anxiety Pregnant Mother In Facing Labor', 8(1), Pp. 32-36.

Dirjen Kesmas (2020) Pedoman Bagi Ibu Hamil, Ibu Nifas Dan Bayi Baru Lahir Selama Social Distancing. Jakarta. 
Tiyara Safitri, Sri Sumarni, Aris Santjaka

Dolatian, M. Et Al. (2017) 'The Structural Model Of Spirituality And Psychological Well-Being For Pregnancy-Specific Stress', Journal Of Religion And Health, 56(6), Pp. 2267-2275.

Durankuş, F. And Aksu, E. (2020) 'Effects Of The Covid-19 Pandemic On Anxiety And Depressive Symptoms In Pregnant Women: A Preliminary Study, Journal Of Maternal-Fetal And Neonatal Medicine. Taylor \& Francis, 0(0), Pp. 1-7. Doi: 10.1080/14767058.2020.1763946.

Dwidiyanti, M. Et Al. (2019) The Art Of Mindfulness Spiritual Islam. 1st Ed. Semarang: Undip Press.

Dwidiyanti, M., Pamungkas, A. Y. . And Ningsih, H. E. . (2018) Mindfulness Caring Pada Stress. 1st Ed. Semarang: Undip Press.

Faizah, A. U. And Sudarmiati, S. (2017) 'Hubungan Antara Spiritualitas Dengan Kecemasan Pada Ibu Hamil Primigravida Trimester Iii Di Puskesmas Ngesrep', (Doctoral Dissertation, Faculty Of Medicine).

Fisher, C. Et Al. (2012) 'Participant Experiences Of Mindfulness-Based Childbirth Education: A Qualitative Study, Bmc Pregnancy, And Childbirth, 12(1), P. 126. Doi: Https://Doi.Org/10.1186/1471-2393-12-126.

Fitriyani, N. Et Al. (2018) 'Terapi Kecemasan Dalam Konseling Islam'.

Hall, H. Et Al. (2015) 'The Effectiveness Of Mindfulness Training On Perinatal Mental Health; A Systematic Review.', Integrative Medicine Research, 4, P. 125. Doi: Https://Doi.Org/10.1016/J.Imr.2015.04.233.

Harahap, F. S. D. (2018) 'Keseimbangan Fisik, Psikis, Dan Spiritual Islam Pada Masa Kehamilan Dan Persalinan', Jurnal Psikologi Islam, 5(1), Pp. 1-12.

Heriani, H. (2016) 'Kecemasan Dalam Menjelang Persalinan Ditinjau Dari Paritas, Usia Dan Tingkat Pendidikan', Jurnal Aisyah: Jurnal Ilmu Kesehatan, 1(2), P. Hal-01.

Ibanez, G. Et Al. (2015) 'Effects Of Antenatal Maternal Depression And Anxiety On Children's Early Cognitive Development: A Prospective Cohort Study, Plos One. Public Library Of Science San Francisco, Ca Usa, 10(8), P. E0135849.

Ifantri, J. (2015) 'Pengaruh Jumlah Daun Dan Jenis Pupuk Kandang Terhadap Pertumbuhan Dan Hasil Melon (Cucumis Melo L.)', Universitas Pgri Yogyakarta.

Jayanti, R. (2016) 'Efektivitas Pelatihan Mindfulness Dengan Pendekatan Spiritual Terhadap Peningkatan Psychological Wellbeing Penderita Diabetes Mellitus Tipe 2'.

Kartikasari, A., Hadisaputro, S. And Sumarni, S. (2020) 'Pengaruh Prenatal Yoga Terhadap Lamanya Persalinan Kala I Kontraksi Uterus Dan Perubahan Kadar Hormon Endorphin Pada Ibu Primigravida Studi Kasus Di Puskesmas Kadugede Kuningan Jawa Barat', Jurnal Ilmu Kesehatan Bhakti Husada: Health Sciences Journal, 11(1), Pp. 27-37.

Karyati, S. (2016) 'Aplikasi Terapi Murotal Al-Qur'an Dan Komunikasi Terapeutik Sebagai Upaya Menurunkan Tingkat Kecemasan Persalinan', The 4 Th Univesity Research Coloquium, Pp. 175-182.

Kuswandy, L. (2011) Keajaiban Hypnobirthing. Jakarta: Pustaka Bunda. 
Matvienko-Sikar Et Al. (2020) 'Perinatal Mental Health During The Covid-19 Pandemic', Women And Birth. Australian College Of Midwives, 33(4), Pp. 309-310. Doi: 10.1016/J.Wombi.2020.04.006.

Munkhondya, B. M. J. Et Al. (2020) 'Efficacy Of Companion-Integrated Childbirth Preparation For Childbirth Fear, Self-Efficacy, And Maternal Support In Primigravid Women In Malawi', Bmc Pregnancy And Childbirth. Springer, 20(1), Pp. 1-12.

Nurrochmi, E., Nurlina, N. And Padmawati, R. (2019) 'Persiapan Spiritual Sebagai Upaya Menghadapi Persalinan Yang Nyaman Di Wilayah Kerja Puskesmas Pamitran Kota Cirebon 2018', 1(2), Pp. 115-119.

Nurya Viandika, S. S. T., Kes, M. And Husada, Stik. C. (No Date) 'Menyambut Buah Hati: Persiapan Ibu Hamil Di Masa Pandemi', Adaptasi Kebiasan Baru Dalam Kebidanan Di Era Pandemi Covid-19, P. 183.

Organization, W. H. (2014) Trends In Maternal Mortality: 1990 To 2013: Estimates By Who, Unicef, Unfpa, The World Bank And The United Nations Population Division: Executive Summary. World Health Organization.

Parrott, J. (2017) 'How To Be A Mindful Muslim: An Exercise In Islamic Meditation', In.

Perrin, A. (2015) 'Social Media Usage: 2005-2015', (October), Pp. 2005-2015.

Prapto, D. A., Nashori, F. And Rumiani, R. (2015) 'Terapi Tadabbur Al-Qur'an Untuk Mengurangi Kecemasan Menghadapi Persalinan Pertama', Jip (Jurnal Intervensi Psikologi), 7(2), Pp. 131-142.

Prawirohardjo, S. (2008) 'Ilmu Kebidanan Yayasan Bina Pustaka'. Jakarta.

Putri, D. A. And Yuliandari Gunatirin, E. (2020) 'Mindful-Based Cognitive Therapy (Mbct) Dan Self-Awareness Untuk Menurunkan Kecemasan Ibu Hamil Primipara', Journal An-Nafs: Kajian Penelitian Psikologi, 5(1), Pp. 1-24. Doi: 10.33367/Psi.V5i1.878.

Rifaldy, G. (2019) 'Pengaruh Konsentrasi Pupuk Organik Cair Dan Takaran Pupuk Nitrogen Terhadap Pertumbuhan Dan Hasil Tanaman Cabai Rawit (Capsicum Frutescens L.) Kultivar Dewata F1', Agroswagati Jurnal Agronomi, 7(2), Pp. 87-95.

Riska, H., Purwara, B. H. And Ganiem, A. R. (2020) 'Pengaruh Virtual Reality Dalam Menurunkan Kecemasan Menghadapi Persalinan Pada Primigravida', Jurnal Kesehatan Prima, 14(1), Pp. 31-39.

Ritsma Zunira Aryani, Rohmi Handayani, D. S. (2018) 'Pengaruh Pelaksanaan Prenatal Gentle Yoga Terhadap Kecemasan Menjelang Persalinan Pada Ibu Hamil Primigravida Trimester Iii Di Klinik Bidan Kita Klaten Ritsma Zunira Aryani, Rohmi Handayani, Dewi Susilowati', Jurnal Kebidanan Dan Kesehatan Tradisional, 3(2), Pp. 78-83.

Sandall, J. Et Al. (2016) 'Midwife - Led Continuity Models Versus Other Models Of Care For Childbearing Women. Cochrane Database Of Systematic Reviews, (4)'. 
Setiawan, D., Aji, M. P. And Astuti, B. (2020) 'Pembuatan Elektroda Berbahan Air Cucian Beras', In Prosiding Seminar Nasional Pascasarjana (Prosnampas), Pp. 200-206.

Shodiqoh, E. R. And Syahrul, F. (2014) 'Perbedaan Tingkat Kecemasan Dalam Menghadapi Persalinan Antara Primigravida Dan Multigravida', Jurnal Berkala Epidemiologi, 2(1), Pp. 141-150.

Stoll, K. Et Al. (2016) 'Cross-Cultural Development And Psychometric Evaluation Of A Measure To Assess Fear Of Childbirth Before Pregnancy', Sexual \& Reproductive Healthcare. Elsevier, 8, Pp. 49-54.

Sugiyono (2014) Metode Penelitian Kuantitatif Kualitatif Dan R\&D. Bandung: Alfabetha.

Sutrisno, S. And Wulandari, D. (2018) 'Multivariate Analysis Of Variance (Manova) Untuk Memperkaya Hasil Penelitian Pendidikan', Aksioma: Jurnal Matematika Dan Pendidikan Matematika, 9(1), Pp. 37-53.

Ward, J., Clarke, R. And Linden, R. (2009) At A Glance Fisiologi. Jakarta: Erlangga.

Wardiah, W., Linda, L. And Rahmatan, H. (2014) 'Potensi Limbah Air Cucian Beras Sebagai Pupuk Organik Cair Pada Pertumbuhan Pakchoy (Brassica Rapa L.)', Jurnal Biologi Edukasi, 6(1), Pp. 34-38.

Who (2020) Corona Virus.

Wu, Y. Et Al. (2020) 'Perinatal Depressive And Anxiety Symptoms Of Pregnant Women During The Coronavirus Disease 2019 Outbreak In China', American Journal Of Obstetrics And Gynecology. Elsevier Inc., 223(2), Pp. 240.E1-240.E9. Doi: 10.1016/J.Ajog.2020.05.009.

Yuniarti Et Al. (2016) 'Influence Of Spiritual Therapy Emotional Freedom Technique (Seft) On Cortisol Levels And Immunoglobulin E (Study Of Anxiety In Pregnant Women In Independent Practice Midwives Semarang)', (2010), Pp. 318-323.

Zengin, H. Et Al. (2020) 'Childbirth And Postpartum Period Fear And The Related Factors In Pregnancy'. Coll Physicians \& Surgeons Pakistan 